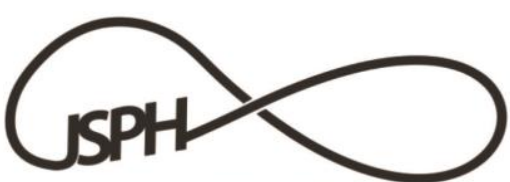

Jurnal Sosiologi Pendidikan Humanis

\title{
NARASI KUASA PEREMPUAN PEKERJA BISNIS ONLINE
}

\section{Sih Natalia Sukmi}

\section{Universitas Kristen Satya Wacana}

Email : sih.natalia@ staff.uksw.edu

\begin{abstract}
Abstrak
Jumlah angkatan kerja di Indonesia mengalami peningkatan seiring dengan jumlah partisipasi perempuan untuk bekerja. Faktanya deskriminasi perempuan dalam sector ekonomi formal dan informal belum terselesaikan. Di sisi lain internet memberi peluang bagi perempuan untuk bekerja tanpa harus meninggalkan rumah. Penelitian ini bertujuan untuk mengidentifikasi bagaimana konstruksi sosial perempuan pekerja usaha online terhadap definisi kerja dan bagaimana teknologi (internet) memberi kuasa bagi perempuan untuk mengembangkan keberdayaan mereka. Penelitian ini mendiskusikan teori kuasa pendekatan Michel Foucault dan Gramsci untuk memahami bagaimana kuasa digunakan perempuan dalam interaksinya dengan teknologi dan sistem patriaki serta sistem sosial budaya yang lebih luas. Metodologi yang digunakan adalah deskriptif eksploratif. Hasil penelitian menunjukkan bahwa perempuan mempunyai kuasa terhadap teknologi. Dia mendapat keuntungan secara praktis seperti menghasilkan pendapatan, lebih dihargai dan dapat berinteraksi dengan lingkungan di luar. Namun ketika diperhadapkan dengan sistem patriakri dan sistem sosial yang lebih luas, perempuan nyatanya powerless. Dia terhegemoni dengan status keperempuanannya dengan menyebut dirinya "bukan pekerja", hanya "menambah penghasilan suami" dan tetap berbeban ganda untuk menjaga keseimbangan wilayah domestik dan publik.
\end{abstract}

Kata kunci : Perempuan, Kuasa, Usaha Online

\section{NARRATION OF WOMEN'S POWER ONLINE BUSINESS WORKERS}

\begin{abstract}
The number of workforce in Indonesia has increased along with the number of female participation to work. The fact that discrimination in women in the formal and informal economic sectors has not been resolved. On the other hand the internet provides opportunities for women to work without having to leave home. This study aims to identify how the social construction of women business workers online against the definition of work and how technology (the internet) gives power to women to develop their empowerment. This study discusses the power theory of Michel Foucault and Gramsci's approach to understanding how the power of women's use in their interactions with patriarchal technology and systems and the wider socio-cultural system. The methodology used is descriptive explorative. The results showed that women have power over technology. He gains practical benefits such as generating income, being valued and able to interact with the outside environment. But when faced with a patriarchal system and a wider social system, women are in fact powerless. He was hegemony with his feminine status by calling himself "not a worker", only "increasing the husband's income" and still having a double burden to maintain the balance of domestic and public areas.
\end{abstract}

\section{Keywords : Women, Power, Online Businesses}




\section{LATAR BELAKANG}

Berdasarkan data BPS, jumlah angkatan kerja di Indonesia mengalami peningkatan sebesar 2,39 juta pada Februari 2018 dibanding Februari 2017. Total angkatan kerja diperkirakan mencapai 133,94 juta (BPS, 2018). Peningkatan ini terkait lonjakan jumlah partisipasi pekerja perempuan perkotaan yang masuk dalam angkatan kerja. Walaupun faktanya, kesenjangan gender dalam partisipasi angkatan kerja laki-laki dan perempuan masih tinggi, yaitu 85,0 persen dan 53,4 persen pada Februari 2014. Kesenjangan terjadi pula pada formalitas pekerjaan. Perempuan cenderung bekerja di sektor perekonomian informal (57,9\%) dibanding laki-laki (50,9\%). Jumlah tersebut berhubungan dengan masih adanya diskriminasi terhadap perempuan.

Diskriminasi terhadap perempuan pekerja dipicu dari pemahaman dasar tentang definisi kerja. Berdasarkan UU Republik Indonesia No.13 Tahun 2003 tentang ketenagakerjaan, yang dimaksud dengan tenaga kerja adalah setiap orang yang mampu melakukan pekerjaan guna menghasilkan barang dan/atau jasa baik untuk memenuhi kebutuhan sendiri maupun untuk masyarakat. Sementara definisi pekerja/buruh adalah setiap orang yang bekerja dengan menerima upah atau imbalan dalam bentuk lain. Studi tentang perempuan pekerja di Jawa menunjukkan bahwa perempuan memiliki jam kerja lebih banyak dibanding dengan laki-laki, seperti mengurus keluarga, mengumpulkan kayu, dll. Namun karena pekerjaan ini tidak berbayar, maka masyarakat memahaminya bukan pekerjaan (Beninghausen \& Kerstan, 1992:80 dalam Blackburn, 2004:168). Diskusi lain menyangkut kekuatan pekerja adalah pemahaman yang lebih mengedepankan sektor formal dibanding sektor informal.

"...whereas most women still work in the informal sector, for example on family farm and in family enterprises; within the home, doing piece-work for factories; as domestic workers in other people's homes; as prostitutes; or as petty traders selling small quantities of goods" (Blackburn, 2004:168).

Pemahaman yang lain perempuan pekerja adalah persoalan peran dan upah. Perempuan pekerja dipandang bukan sebagai subyek utuh namun sebagai pengganti laki-laki, bahkan ketika perempuan memiliki upah lebih besar dibanding laki-laki (Maning, 1998:235). Kenaikan jumlah angkatan kerja perempuan juga tidak selalu berimplikasi positif terhadap peluang kerja perempuan atau alasan mengapa perempuan dipilih menjadi pegawai dalam sebuah perusahaan. Perempuan tidak serta merta dipekerjakan karena dia memiliki kapasitas yang lebih baik dari sisi kecocokan terhadap jenis pekerjaan atau kemampuan dia untuk menyelesaikan pekerjaan. Sebaliknya perempuan seringkali dipekerjakan karena dianggap sebagai kelompok penurut dan lebih murah sehingga ekonomis bagi perusahaan (Manning, 1980; Mather, 1982; Elson\&Pearson, 1984; Sayogjo,1989).

Diskusi tentang diskriminasi perempuan pekerja menjadi lebih menarik manakala perempuan kini dianggap berpeluang untuk menghasilkan pendapatan melalui media baru. Internet dianggap sebagai ruang bagi perempuan untuk menunjukkan empower mereka dalam hal ekonomi. Data Kepkominfo menunjukkan jumlah pengguna internet di Indonesia mencapai 82 juta orang. Sementara data yang diperoleh dari Asosiasi Penyelenggara Jasa Internet Indonesia (APJII) bekerjasama dengan Teknopreneur menunjukkan bahwa tahun 2017 pengguna internet mencapai 143,26 juta jiwa atau sebanding dengan 54,7 persen dari total masyarakat Indonesia. Lonjakan yang cukup signifikan mengingat di hingga akhir tahun 2014 jumlah pengguna internet sebanyak 88,1 juta jiwa dari 252.4 juta jiwa, sehingga penetrasi pengguna internet mencapai 34.9\%. Tahun 2017 komposisi pengguna internet berdasar jenis kelamin sebesar 48,57\% perempuan dan 51,43\% laki-laki. 
Data riset pemasaran majalah online Marketeers memperlihatkan trend berbelanja online menggunakan ponsel cerdas naik signifikan hingga 80\% pada tahun 2017 dari angka 68\% di tahun 2015. Artinya aktivitas ekonomi berbasis industri e-commerce menunjukkan geliatnya. Alasan tersebut mengarah pendapat beberapa pengamat ekonomi bahwa perempuan sangat berpeluang masuk dalam bisnis online untuk meningkatkan keberdayaan mereka dalam bidang ekonomi. Berdasar atas latar belakang tersebut maka penelitian ini bertujuan untuk mengidentifikasi bagaimana konstruksi sosial perempuan pekerja usaha online terhadap definisi kerja dan bagaimana teknologi (internet) memberi kuasa bagi perempuan untuk mengembangkan keberdayaan mereka. Kuasa dalam penelitian ini akan ditinjau dari dua pendekatan, yaitu pendekatan Michel Foucault dan Gramsci.

\section{METODE PENELITIAN}

Penelitian ini dilakukan terhadap perempuan yang berasal dari salah satu daerah di Jawa Timur, Jawa Tengah dan Jawa Barat dengan metode wawancara mendalam. Informan yang dipilih secara purposive dengan kriteria informan yaitu seorang perempuan yang memiliki usaha online dalam bidang yang tidak dibatasi. Dalam penelitian ini terkumpul data dari 15 informan dengan usia antara 25-35 tahun. Alasan pemilihan usia ini dimaksudkan bahwa perempuan antara usia 25-35 tahun di Indonesia lazimnya sudah menikah dan menjadi keluarga muda. Selain melihat interaksi perempuan dengan teknologi, penelitian ini juga meninjau interaksi perempuan dengan keluarganya. Perempuan yang dipilih juga seorang perempuan yang berpendidikan minimal S1 dengan perekonomian kelas menengah ke atas. Hal tersebut mengindikasikan bahwa mereka terpapar teknologi. Selain itu, perempuan yang berpendidikan diasumsikan mempunyai kemampuan lebih dalam mengekspresikan kehendaknya. Riset tentang relasi teknologi dengan perempuan dengan perekonomian menengah ke bawah telah dilakukan (Bahfen \& Baggaley, 2006). Selain melakukan wawancara mendalam, penelitian ini juga menggunakan focus group discussions dan observasi dalam proses pengumpulan data.

\section{HASIL DAN PEMBAHASAN}

\section{Diskusi tentang Kuasa}

Kuasa sering dipahami melalui lensa negatif sebagai dominasi, homogen dan represif. Menurut Weber, "power is defines as the probability that one actor within a social relationship will be in a position to carry out his own will despite resistance, regardless of the basis on which this probably rests." Konsekuensinya Weber menyamakan kuasa dengan dominasi. Dominasi olehnya dibagi menjadi dua yaitu: indirect type dimana power diasumsikan sebagai monopoli atas sumber-sumber ekonomi dan direct type yang dipahami sebagai kontrol atas yang lain (Durkheim, 1964; Sydie, 1987). Dalam aturan traditional, kuasa dikelola dalam kebiasaan patrimonial dimana patriaki menjadi bentuk dasarnya. Patriaki sendiri merupakan bentuk karakteristik dominasi kelompok rumah tangga atau klan yang diorganisasikan dalam istilah kekerabatan dan ekonomi (Sydie, 1987). Sehingga dalam hukum ini berarti wewenang ada pada ayah, atau suami, atau senior dalam rumah.

Penting untuk dipahami bahwa power tidak akan dapat bekerja sendiri. Power sangat dipengaruhi oleh agen serta sistem sosial yang melingkupinya. Oleh karena itu legitimasi power perlu dipahami secara mendalam untuk mengetahui bagaimana power bekerja. Penelitian ini akan didekati dengan dua teori power. Teori yang akan didiskusikan adalah teori power milik Michel Foucault dan teori hegemoni Gramsci. Michel Foucault memandang kuasa bukanlah sebuah fungsi kesadaran, kuasa bekerja saat digunakan (excercising). Kuasa juga tidak dimiliki oleh subyek tertentu melainkan eksis pada tindakan yang mengekspresikan kuasa itu sendiri. Seperti ungkapan Foucault berikut, 
"Power must be analysed as something which circulates, or rather as something which only functions in the form of a chain. It is never localised here or there, never in anybody's hands, never appropriated as a commodity or piece of wealth. Power is employed and exercised through a net-like organisation. And not only do individuals circulate between its threads; they are always in the position of simultaneously undergoing and exercising this power. They are not only its inert or consenting target; they are always the elements of its articulation. In other words, individuals are the vehicles of power, not its point of application" (Foucault, 1980: 98).

Foucault

(1997:544-546)

mengeksternaliasi kuasa dalam berbagai hubungan anonim sebagai praktik standar dan memahami subyek sebagai produk yang sama. Dia menambahkan bahwa kuasa ada ketika dia diletakkan dalam sebuah aksi sebagai seperangkat tindakan terhadap tindakan yang lain. Bagi Faucoult, kekuasaan ada dimana-mana karena kekuasaan adalah satu dimensi dari relasi. Dimana ada relasi disana ada kekuasaan (Bertens, 2001:319). Kuasa itu ada di mana-mana dan muncul dari relasi-relasi antara pelbagai kekuatan, terjadi secara mutlak dan tidak tergantung dari kesadaran manusia. Kekuasaan hanyalah sebuah strategi. Strategi ini berlangsung di mana-mana dan di sana terdapat sistem, aturan, susunan dan regulasi. Kekuasaan ini tidak datang dari luar, melainkan kekuasaan menentukan susunan, aturan dan hubungan-hubungan dari dalam dan memungkinkan semuanya terjadi (Foucault, 2000:144)

Bagi Foucault, power dipandang sebagai sesuatu yang meresap dalam cara berpikir, cara berbicara dan cara berperilaku, sehingga seseorang yang memiliki power akan menghasilkan cara pandang terhadap dunia dan dirinya sendiri. Seseorang yang memiliki power bagi Foucault juga dapat mendisiplinkan dirinya menjadi subject yang dikehendakinya (Foucault ,1979; Gordon, 1982). In this way, individuals are 'disiplined' by 'disipline' then the disipline is self disipline and the control is self-control (Brocklehurst, 2010). Dalam penelitian ini, kuasa diasumsikan ketika perempuan pekerja menggunakan teknologi, dalam hal ini internet untuk melakukan bisnis online. Kuasa atas teknologi akan dipandang sebagai kekuatan yang dapat digunakan perempuan untuk meningkatkan keberdayaan mereka dalam aspek ekonomi.

Jika Foucault mendeskripsikan kekuasaan bukan milik perseorangan dan ada dimana-mana. Gramsci memandang bahwa kuasa eksis manakala pihak tersubordinasi memiliki "keinginan kolektif" untuk melakukan sesuatu melalui ideologi tertentu. Gramsci adalah pemikir, filsuf dan aktivis politik. Tak heran jika karyanya merupakan ekspresi dari fenomena sosial yang ada di Italia tentang perjuangan kaum buruh melawan rezim fasis dalam pemerintahan Benito Mussolini. Konsep kekuasaan ala Gramsci menjabarkan bahwa kekuasaan tidak senantiasa dilakukan dengan jalan kekerasan. Hegemoni dalam pemahaman Gramsci berupaya mengorganisir kesepakatan bersama melalui terciptanya kesadaran tanpa ada unsur paksaan. Hal ini tidak hanya beroperasi dalam ruang politik namun juga dalam konteks relasi sosial.

\section{Perempuan dan Penggunaan Internet di Indonesia}

Hasil survey Puskakom UI dan APJII menyatakan bahwa ada tiga alasan penggunaan internet bagi masyarakat Indonesia. Penggunaan terbanyak dialokasikan untuk mengakses sarana sosial/komunikasi (72\%), sumber informasi (65\%), dan mengikuti perkembangan zaman (51\%). Salah satu aktivitas yang tengah menjadi tren adalah jual beli online. Jenis situs belanja online yang digunakan masyarakat Indonesia adalah toko online dengan satu penjualan (50,3\%), jejaring sosial $(43,1 \%)$, Forum jual beli (27\%), website $(11,6 \%)$, komunitas online $(9,7 \%)$, mesenger $(8,8 \%)$, dan mailing list $(1,3 \%)$. Keminatan belanja di warung-warung maya 
ini memicu lahirnya toko-toko online atau aplikasi-aplikasi jual beli yang masuk dalam sosial media di Indonesia. Tempat jualan favorit masyarakat Indonesia adalah jejaring sosial (64.9\%). Komoditas utama dalam jual beli online di Indonesia adalah busana (72\%), kosmetik (20\%), perangkat komunikasi $(17 \%)$, jasa travel perjalanan $(9.7 \%)$, dan buku $(9.7 \%)$. Bila dilihat dari 2 jenis komoditas dengan sirkulasi jual beli paling tinggi yaitu busana dan kosmetik maka tidak heran jika perempuan merupakan pengguna mendominasi bisnis online. Hasil survey juga menunjukkan bahwa perempuan lebih berani melakukan belanja online dibanding laki-laki dengan jumlah prosentase $58 \%$ berbanding $42 \%$.

Kondisi ini menjadi peluang bagi perempuan lain untuk memanfaatkan teknologi tidak untuk proses konsumsi namun juga menghasilkan uang sendiri melalui bisnis online. Indonesia mengalami krisis ekonomi sekitar tahun 1996-1997, kondisi ini mengakibatkan banyak orang kehilangan pekerjaan dan pindah ke sektor informal. Perempuan merasa bertanggungjawab pula untuk menangani persoalan finansial keluarga dengan mengambil pekerjaan berbasis rumah. Persoalan yang muncul kemudian bahwa homeworkers di Indonesia tidak dapat dimaknai sebagai pekerja, sehingga tidak dapat tertuang melalui UndangUndang ketenagakerjaan. Proyeksi ILO 2019 menunjukkan bahwa jumlah pekerja meningkat mencapai 14 juta, sedangkan pekerjaan rentan berkurang menjadi $51 \%$ dari total pekerjaan 2019. Namun menjadi persoalan ketika definisi ILO dan Indonesia tentang pekerjaan rentan berbeda. ILO mendefinisikan pekerjaan rentan sebagai pekerja mandiri dan pekerja yang membantu keluarga, sedangkan Indonesia memasukkan buruh harian dan pengusaha yang dibantu pekerja temporer atau pekerja tanpa upah dalam definisi mereka tentang pekerja rentan (www.ilo.org).Pemahaman Indonesia tentang tenaga rentan terkait pula dengan sifat tenaga harian Indonesia yang biasanya bersifat informal dan dicirikan dengan upah yang tidak memadai, produktivitas rendah, dan kondisi kerja yang buruk.

Menurut BPS "Pekerja, adalah seseorang yang bekerja secara permanen untuk orang lain atau lembaga/kantor /perusahaan dan memperoleh uang/tunai atau barang sebagai upah/gaji. Pekerja yang tidak memiliki majikan tetap tidak dikategorikan sebagai buruh/pekerja/karyawan tapi sebagai pekerja harian. Buruh, secara umum, dianggap memiliki majikan tetap jika ia punya majikan yang sama selama satu bulan terakhir, terutama untuk sektor konstruksi bangunan adalah tiga bulan. Jika pemberi kerjanya adalah sebuah lembaga, maka lebih dari 1 (satu) diperbolehkan.

Definisi Indonesia tentang pekerjaan rentan dan definisi ILO tentang pekerjaan rentan agak berbeda. ILO mendefinisikan pekerjaan rentan sebagai pekerja mandiri dan pekerja yang membantu keluarga, sedangkan Indonesia juga memasukkan buruh harian dan pengusaha yang dibantu pekerja temporer/pekerja tanpa upah dalam definisi mereka tentang pekerja rentan. Hal ini dikarenakan sifat pekerjaan harian di Indonesia, yang biasanya bersifat informal dan dikarakteristikkan oleh upah yang tidak memadai, produktivitas rendah dan kondisi kerja yang buruk.

\section{Diskusi Pekerja Rumahan dalam Sistem Patriaki}

Pembagian peran antara laki-laki dan perempuan menurut Marx dan Engels bermula dari pemahaman tentang keluarga. Interaksi dalam keluarga didasarkan pada jenis kelamin yang berdampak pada pembagian jenis kerja antara lakilaki dan perempuan.

"The division of labour within the family and the "separation of society into individual families opposed to one another," as a result of their differential relationship to property, produced the "nucleus" of class divisions, "the first form of which lies in the family, where the wife and children are the slaves of the husband" (Engles, 1972:25).

Sayangnya, dasar berpijak itulah yang tampaknya diadopsi negara untuk membuat kebijakan terkait 
dengan institusi perkawinan hingga ketenagakerjaan. Konsepsi itu pula yang mendasari Engels dalam menentukan faktor dalam konsepsi materialis tentang sejarah yaitu "production and reproduction of immediate life." Walaupun pandangan ini sempat mendapat kritik dari para antropologis namun bagi Engles and Marx tidak memandang ini sebagai problematik. Bahkan ketika mendiskusikan tentang emansipasi, mereka berpendapat;

"The emancipation of women and their equality with men are imposibble and must remain so as long as women are excluded from socially productive work and are restricted to housework, which in private. The emancipation of women becomes possible only when women are enables to take part in production on a large, social scale and when domestic duties their attention only to a minor degree" (Engels, 1972:152).

Perempuan pekerja yang dibayar merupakan pintu masuk diskusi perempuan dalam hubungan kelas. Engels dan Marx menggarisbawahi bahwa hubungan kelas sosial terbentuk dari keterkaitan mereka dengan propertI yang dimiliki dalam keluarga. Perempuan didefinisikan melalui peran domestiknya "sebagai kelompok yang bertanggungjawab terhadap produksi atas hal-hal yang bersifat sederhana terkait aktivitas rumah dan keluarga. Karena laki-laki tidak memiliki tanggung jawab semacam itu maka perbedaan kelompok terletak di sini (Sydie 1987:105).

Hubungan laki-laki dan perempuan dalam konteks ini dipahami sebagai sistem patriaki. Istilah patriaki lahir dari kata 'patriarch'. Kata ini ditujukan untuk menjelaskan dominasi pria dalam relasi keluarga. Namun perkembangannya kini istilah ini dipahami "to refer to male domination, to the power relationships by which men dominate women, an $\mathrm{d}$ to characterise a system whereby women are kept subordinate in a number of ways" (Bhasin 2006, p. 3). Dominasi dalam hubungan laki-laki perempuan menurut kaum feminis terjadi bukan hanya di wilayah privat namun juga di wilayah publik. Patriaki memiliki bermacam definisi, beberapa memahami istilah ini sebagai sistem struktur sosial dan praktis dimana laki-laki mendominasi perempuan. Pemikiran ini bersumber dari ketimpangan gender yang lahir dari sistem sosial dan bukan lahir secara biologis (Mitchell 1971; Walby 1990). Dalam perkembangannya patriaki bahkan tidak hanya dipahami atas dominasi dia atas hubungan dalam keluarga, namun juga institusi masyarakat secara umum (Lerner 1989, p. 239). Sistem dalam interaksi antara laki-laki dan perempuan dalam pandangan patriaki menurut Jagger dan Rosenberg (1984) dipahami sebagai serangkaian hubungan-hubungan sosial antara lakilaki dan perempuan baik terkait material base maupun melalui hirarki membangun atau menciptakan kemerdekaan dan solidaritas antar lakilaki untuk mendominasi perempuan.

\section{Diskusi Kuasa pada Perempuan}

Penelitian ini menunjukkan bahwa perempuan memiliki kuasa terhadap teknologi. Bagi perempuan yang belum menikah, alasan mereka terjun di bisnis online untuk menambah penghasilan. Selain bekerja di perusahaan formal, bisnis online dianggap sebagai usaha sampingan yang dapat meningkatkan pendapatan mereka. Seperti yang diungkap Dian (28 tahun) yang kesehariannya bekerja sebagai seorang peneliti kandungan gizi di perusahaan makanan, "Sebenarnya gajiku usah cukup untuk kebutuhanku, cuma kalau bisa dapat tambahan dari bisnis olshop kenapa nggak, toh tidak menyita waktu yang sangat ekstrim. Aku bisa kerjain di waktu istirahat, pulang kantor atau weekend, lagian juga bisa diurus dimana aja." Sebanding dengan Dian, Tantri mengungkapkan, "Online shop itu buat aku sudah kayak mainjob, soalnya penghasilannya lebih dari gajiku. Sudah waktunya fleksibel, operasikannya sambil kerjain lain bisa. Walau kalau seperti sekarang memang butuh waktu khusus sih, karena omzetku udah mulai besar dan order udah banyak banget." Keunggulan lain ketika 
bisnis online adalah mereka dapat mengerjakan bisnis ini dimanapun mereka bisa. Tempat menjadi fleksibel, "Enak kalo jualan online, ga repot dandan, bangun tidur aja langsung bisa kerja," ungkap Tantri.

Ketika ditanya mengapa mereka tetap bekerja di sektor formal sementara mereka dapat berpenghasilan besar melalui bisnis online, Tantri menjawab,"Nah itu masalahnya, orang tuaku pikir kalau usaha online itu ga kerja, dia penginnya aku pakai baju rapi berangkat kantor pulang sore. Jadi cucok yang kuliah. Dulu sempat mau keluar dan urus bisnis online, orang tuaku bilang. Ya kalau laku terus gapapa, kalau ga, nanti kamu makan apa? Wong di sekolahin tinggi-tinggi kok ijazahnya ga dipakai." Penjelasan tersebut menunjukkan bahwa usaha online bagi masyarakat tidak dipandang sebagai kerja. Ekspektasi kerja masyarakat adalah menjadi bagian dari sektor formal. Giddens (1973, p. 288) berpendapat bahwa sekalipun perempuan menjadi pekerja yang dibayar, hal itu tetap tidak memberi legitimasi langsung atas struktur kelas. Pekerja perempuan tetap dianggap sebagai kelompok periferi dalam sistem kelas atau dengan kata lain perempuan masuk dalam "underclass" dari sektor kelompok kerah putih.

\section{Diskusi Power dalam Interaksi Perempuan dan Sistem Patriaki}

Sementara bagi perempuan yang sudah menikah usaha online adalah bisnis yang menguntungkan. Ruang menjadi hal yang penting bagi perempuan yang telah menikah. Bagi mereka, bisnis online tidak memaksa mereka keluar rumah. Mereka dapat mengurus anak dan menyelesaikan urusan domestik sambil berbisnis. Tidak hanya untung dari sisi waktu, mereka juga mendapat penghasilan sendiri. Seperti pendapat Amel, "Saya senang karena dapat uang sendiri lewat internet". Senada dengan Amel, Septi mengatakan, "Ya senang lah, karena tanpa kemana-mana aku dapat uang tambahan, tidak perlu minta uang suami kalau ada kebutuhan-kebutuhanku sendiri." Mila menambahkan, "Kalau anakku butuh apa-apa kalau pegang uang sendiri kan beda."

Kemampuan perempuan untuk menciptakan penghasilan sendiri membuat perempuan merasa lebih menghargai diri mereka. Amel mengungkapkan, "Kadang kalau pas hokinya bagus, uang yang saya dapat lebih besar dapetnya dari suami saya loh." Ekspresi bahagia tergambar ketika dia mengungkapkan pernyataan tersebut. Finansial merupakan sesuatu yang sering menjadi problematik perempuan Indonesia. Salah satu alasan kekerasan dalam rumah tangga di Indonesia terkait pula dengan persoalan finansial keluarga. Melalui bisnis online, perempuan mendapat tambahan pemasukan selain gaji yang mereka peroleh dari suami untuk kebutuhan rumah tangga.

Kemampuan perempuan untuk menghasilkan uang mempengaruhi pola interaksi perempuan dan laki-laki dalam hubungan keluarga. Suami yang isterinya mampu menghasilkan penghasilan sendiri lebih menghargai isterinya. Mila mengungkapkan, "Sejak online shopku jalan, suamiku jadi lebih peduli, kalau aku bilang capek dan ngajak gentian ngurus anak dia mau bantu urus anak. Walau kalau dia capek di kantornya ya aku pontang-panting sendiri." Demikian pula jawaban dari Aermi, dia mengungkapkan demikian, "yah karena aku bisa cari duit sendiri kan sedikit-sedikit ga minta suami, jadi aku lebih leluasa untuk ngapangapain. Dulu kalo mau nyumbang aja minta, mau kasih ke orang tua juga minta, rasanya ga enak juga. Ga hanya itu, tahu kalau bisa nambah-nambah penghasilan sekarang suamiku malah beliin aku laptop plus langganan speedy, katanya biar lancar aksesnya."

Kuasa terhadap teknologi dirasakan perempuan bukan hanya dari sisi finansial, perempuan juga merasa memperoleh ruang untuk mengeksplorasi kemampuan mereka. Aktualisasi diri dapat mereka salurkan melalui internet, "Ga cuma uang, saya jadi punya temen banyak gara-gara sosmed," ungkap Mila. Bukan hanya dapet duit tapi juga dapat saudara. Lumayan buat isi waktu luang, 
jadi ga bosen di rumah urus anak aja." Dian mengungkapkan hal serupa, "kalau punya olshop tu buat kita jadi ga suntuk, otak kita jadi mikir gimana caranya biar laku. Seru deh! Lagian selain jualan kita juga bisa rumpi soal anak, keluarga, tukar-tukar info ada diskon pampers yang murah ga, gitu."

Meningkatnya ruang sosial di dunia maya sangat terasa bagi perempuan yang tidak bekerja dalam sektor formal. Perempuan yang tidak bekerja di sektor formal memiliki sedikit waktu untuk bersosialisasi dalam dunia nyata, mereka sibuk dengan urusan domestik terlebih lagi jika mereka memiliki seorang bayi. Sebagian besar narasumber dalam penelitian ini mengaku keluar dari tempat mereka bekerja demi menjaga anak yang mereka lahirkan. Aermi mengungkapkan, "ya dulu kan emang kerja di bank, tapi setelah melahirkan aku ga bisa bagi waktu. Apalagi aku sempat kena baby blues jadi ga bisa konsentrasi kerja. Dan kasihan juga kalau anak diurus pembantu. Takut kalau kenapanapa." Alasan sejenis juga diungkap Mila, "Susah bagi waktunya. Dulu memang sudah komit dengan suami kalau aku berhenti kerja kalau sudah punya anak."

Foucault berpendapat bahwa kuasa dapat diamati ketika dia eksis dalam prakteknya. Dalam relasi antara perempuan dan internet, perempuan merupakan subyek yang berkuasa. Dia dapat menggunakan teknologi untuk kepentingan dan tujuan dia. Perempuan yang berbisnis online berkuasa untuk menghasilkan pendapatan, mengaktualisasi diri, dan berinteraksi dengan sosial masyarakat melalui media baru.

Namun di sisi lain ada kontradiksi yang tampak ketika perempuan diperhadapkan dengan sistem sosial budaya yang berlaku di masyarakatnya. Hukum patriaki begitu jelas bekerja dan mempengaruhi perspektif mereka tentang kedudukan dan konstruksi identitas mereka. Hasilnya kuasa yang mereka dapatkan melalui interaksi dan konstruksi mereka terhadap teknologi menjadi powerless. Bagi perempuan yang belum menikah, perempuan harus tetap memenuhi ekspektasi keluarga dan masyarakat untuk bekerja di sektor formal. Pandangan ini juga terkait erat dengan definisi negara tentang kerja. Sistem sosial masyarakat memandang bahwa bisnis online bukanlah sebuah pekerjaan.

Bagi perempuan yang telah menikah dan utamanya menjadi ibu muda ketidakberdayaan mereka terhadap sistem sosial seperti patriaki sangat kentara. Ketika ditanya mengenai apakah tidak merasa sayang meninggalkan karier yang mereka bangun. Mereka sepakat bahwa mereka pada dasarnya juga sangat ingin bekerja di sektor formal. Hal tersebut terkait dengan jenjang pendidikan yang mereka raih. Mereka merasa sia-sia jika tidak gunakan gelar mereka untuk bekerja. April mengungkapkan, "Ya tetep pengin lah, eksis di kantor. Tapi mau gimana lagi, aku kan harus jaga anakku. Kalau bukan aku siapa lagi." Mila juga mengungkapkan hal serupa, "Pengin banget, dulu kan aku produser tv. Kerja bisa seharian, tiap hari seperti ga ada waktu istirahat. Tapi aku menikmati banget. Nah kalau sekarang jelas ga mungkin gitu lagi kan. Sudah ada anak. Yah terima aja, namanya juga kodrat, ga bisa dilawan kan." Pilihan kata kodrat oleh Mila mengekpresikan ketidakberkuasanya dia atas kondisi yang menerpanya. Secara pasrah Mila menganggap bahwa mengurus anak adalah tanggungjawab dia secara penuh. Bukan beban bersama yang dapat dikompromikan dengan suami dan keluarga. Dia merasa tak berdaya dan menganggap ini sebagai kealamiahan yang harus diterima semua perempuan tanpa perlawanan. Perempuan cenderung mengalah karena baginya tugas utama adalah menjaga anak dan keluarga.

"Exploitation speaks to economic reality of capitalist class relations for men and women, whereas oppression refers to women and minorities defined within patriachal, racist, and capitalist relations. Exploitation is what happens to men and women workers in the labor force; woman's oppression occurs from 
her exploitation as a wage-laborer but also occurs from the relations that define her existence in the patriachal sexual hierarchy-as mother, domestic laborer, and consumer" (Eisenstein 1979).

Dari data yang didapatkan menunjukkan pula bahwa perempuan merasa bertanggungjawab penuh untuk menjaga keseimbangan dan keharmonisan keluarga. Probo menyatakan, "Aku memang dapat uang dari jualan di internet, tapi kalau pas anakku sakit atau suamiku kerja di luar kota ya terpaksa aku harus off dari olshopku. Sayang sih, tapi itu bukan pilihan. Aku harus bisa pilih prioritas dan keluarga itu jadi tanggungjawabku."

Bisnis online yang dijalankan oleh ibu muda juga dilakukan di sela-sela waktu mereka mengurus anak. "Ya pas anakku tidur siang atau malam, aku baru urus. Soalnya kalau pas ga tidur ga bisa, anakku kan aktif banget," ungkap Amel. Probo juga sependapat, "Pas duduk-duduk nungguin dia playgroup itu waktu yang pas aku gerilya untuk tangkap target.”

Hukum patriaki ternyata tidak hanya membuat perempuan merasa memiliki beban ganda untuk selesaikan tugas domestik dan kebutuhan aktualisasi diri. Nilai yang tertanam bahwa suami atau laki-laki adalah sosok yang harus bertanggungjawab penuh terhadap finansial dan istri yang harus mengurus rumah tangga masih begitu melekat dan berpengaruh kuat bagi perempuan dalam memaknai kerja. Bagi perempuan usaha online hanyalah cara dia untuk membantu suami. Kata "nambah-nambah pemasukan" digunakan perempuan untuk mengekspresikan bahwa usaha ekonomi yang dia lakukan bukanlah hal penting bagi sistem atau keberlangsungan sistem, dalam lingkup kecil keluarga dan masyarakat lebih luas. Perempuan tidak berpikir atau memberi perlawanan bahwa diapun memiliki hak yang sama untuk mengaktualisasi dirinya atau memiliki kuasa atas waktu untuk pemanfaatannya seperti kehendaknya, misal keinginannya untuk bekerja.
Bahkan ketika omzet berjualan dia melebihi gaji suami, perempuan juga tidak merasa bahwa dirinya berhak mendapat kesetaraan untuk berbagi waktu dan tenaga dalam mengurus anak.

Dalam pemahaman seperti ini, tampak bahwa "hegemoni" ala Gramsci merupakan kata yang tepat untuk mengistilahkannya. Hegemoni digunakan untuk mengekspresikan bahwa kuasa dapat bekerja tanpa menggunakan kekerasan. Kesadaran akan ideologi tertentu seolah natural terjadi dan demikianlah seolah-olah seharusnya berjalan. Perempuan tidak merasa bahwa ada gap dalam interaksinya dengan masyarakat terkait pemahaman kerja. Lingkungan dan sistem nilai patriaki melemahkan perempuan untuk mengkritisi bahwa relasi dan sistem ini mendudukkan mereka dalam sebuah definisi kerja yang perlu dikoreksi.

\section{PENUTUP}

Penelitian ini menggaris bawahi bagaimana kuasa bekerja dalam interaksi perempuan dengan teknologi dan interaksi perempuan dengan sistem patriaki dan sistem sosial yang lebih luas. Bila dapat digambarkan lihat gambar 1.,

Dalam penggunaan teknologi internet, perempuan berkuasa. Dia memiliki kuasa untuk (power to) menggunakan internet sesuai dengan kehendak dirinya. Secara praktis, perempuan memiliki kuasa dengan menghasilkan uang, berinteraksi dan mengaktualisasi diri. Namun secara strategis dalam interaksinya dengan sistem patriaki dan sistem sosial budaya yang lebih besar perempuan menjadi powerless karena kuasa yang dimilikinya terhadap teknologi serta merta harus menyesuaikan dengan kepentingan diluar kehendaknya. Subyek dibalik sistem patriaki dan sistem sosial budaya masyarakat memiliki kuasa atas (power over) perempuan untuk melakukan sesuatu sesuai kehendak si pemilik kuasa. Power to dan power over digunakan dalam interaksi antara teknologi, perempuan, sistem patriaki dan sistem sosial dan budaya yang lebih luas. Power to digunakan untuk mengekspresikan hubungan antara subyek dan obyek, dimana perempuan berlaku 


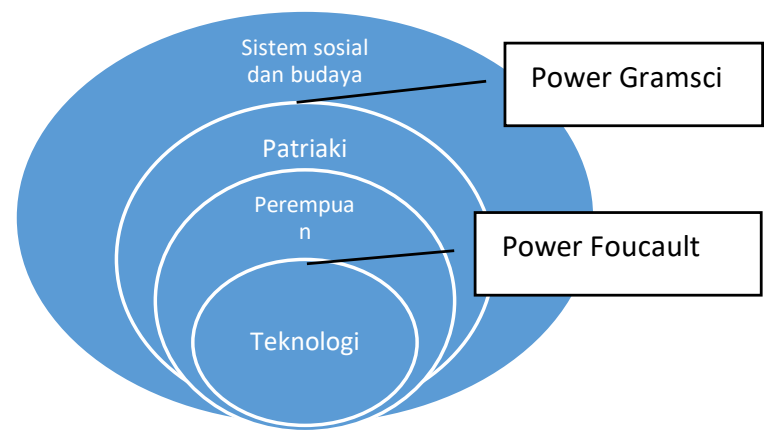

Gambar 1. Sistem Sosial Patriarki Diolah oleh penulis

sebagai subyeknya. Namun hanya sebatas itu saja, perempuan tidak dapat menerapkan power over terhadap laki-laki. Demikian nilai yang diajarkan turun menurun dalam keluarga. The work-family life relationship should take into consideration personal values and self-identity (Clark 2000). Identity is a central concept that determines the 'thickness' (strong) and/or 'thinness' (weak) of the work-home boundaries/borders (Ashforth et al. 2000; Clark 2000; Santos 2015). Bagaimana

perempuan mendeskripsikan diri dalam interaksinya dengan sistem sosial yang lebih luas sangat terkait dengan kemampuan dia menggunakan dan mendefinisikan kuasa. Semakin menarik karena faktanya hampir semua perempuan (seolah) tidak berkeberatan dengan posisinya. Begitu meresap dalam benaknyahingga menjadi identitas- nilai bahwa dia dan hanya dialah yang harus bertanggungjawab terhadap keseimbangan dalam keluarga-wilayah privat dan publik.

Intelektual perempuan ternyata juga tak berdampak signifikan terhadap cara pandang perempuan dalam menempatkan diri dalam masyarakat. Dia tetap berupaya patuh dengan tidak mempertanyakan atau memperdebatkan apa yang menjadi kehendaknya terhadap dalam proses interaksi dalam sistem sosial yang menaunginya. Butler (1990) seorang kontributor feminis yang juga pengikut Foucault memahami power as subjecting, as forming the subject. Sistem patriaki membentuk perempuan yang pasrah menerima kondisi sosialnya. Hal tersebut membuat perempuan menjadi subyek namun tidak memiliki kekuasaan. Foucault (1980, p. 98) menyatakan dalam bukunya "power/knowledge", bahwa power adalah sebuah mekanisme yang menciptakan rasionalitas hukum dan pengetahuan sebagai sebuah alat untuk menegakkan kekuasaan yang lebih besar. Namun, dalam interaksi antara perempuan dan system patriaki tidak demikian. Perempuan telah terhegemoni dalam sistem ini dan dengan kesadaran tanpa paksaan perempuan berupaya menyelaraskan semuanya (lihat gambar 1).

\section{DAFTAR RUJUKAN}

Bahfen, E, Baggaley, J, Trimayuni, PK, Mulyani, L, Harfina, D, Lastrawan, Ratih, D, Retno, CS, Ludher, LL. (2006). Homeworkers and ICTs Indonesia, The ASEAN Foundation, Jakarta.

Beninghausen, J. \& B. Kerstan. (1992). Forging New Paths: Feminist Social Methodology and Rural Women in Java, Zed Books, London.

Bertens, K. (2001). Filsafat Barat Kontemporer Prancis, Gramedia, Jakarta.

Bhasin, K. (2006), What Is Patriarchy Women, Unlimited, New Delhi.

Blackburn, S. (2004). Women and the State in Modern Indonesia, Cambridge University Press, New York, NY.

Brocklehurst, M. (2001). 'Power, Identity and New Technology Homework: Implications for 'New Form' of Organizing', Journal of Organization Studies, 22, 445, 445-466. Viewed $10 \quad$ Agustus 2015, http://oss.sagepub.com/content/22/3/445.

Durkheim, E (1964). The Division of Labor in Society, The Free Press, New York, NY.

Eisenstein, Z. (1979). Developing a Theory of Capitalist Patriachy and Socialist Feminism. In Eisenstein (ed.), Capitalist Patriachy and the Case for Socialist Feminism, Montly Review Press, New York. 
Engles, F. (1972). The Origin of the Family, Private Property, and the State, Pathfinder Press, New York.

Foucault, M. (1980). Power/Knowledge: Selected Interviews and Other Writings 1972-1977, Pantheon Books, New York.

Foucault, M. (2000). Seks dan Kekuasaan terj. S. H. Rahayu, Gramedia, Jakarta.

Giddens, A. (1973). The Class Structure of the Advanced Societies, Hutchinson, London.

International Labour Organization (2014). Indonesia: Tren Sosial dan Ketenagakerjaan: 2014, viewed 11 September 2015, http://www .ilo.org/wcmsp5/groups/public/---asia/--ro-bangkok/---ilojakarta/documents/ publication/wcms_329870.pdf

Kementerian Komunikasi dan Informasi. (2015). Pengguna Internet di Indonesia Capai 82 Juta, viewed 11 Oktober 2015, http://kominfo.go.id/index.php/content/d etail/3980/Kemkominfo\%3A+Pengguna +Internet+di+Indonesia+Capai+82+Juta /0/berita_satker\#.VfwjfPIYaSo

Lerner, G 1989, The Creation of Patriarchy, Oxford University Press, New York.
Manning, C. (1998). Indonesian Labour in Transition: An East Asian Success Story?, Cambridge University Press, Cambridge.

Mitchell, J. (1971) Women's Estate, Penguin, Harmondsworth.

Profil Pengguna Internet Indonesia 2014. (2015). Pusat Kajian Komunikasi Universitas Indonesia (Puskakom) UI dan Asosiasi Penyelenggara Jasa Internet Indonesia. Jakarta: Asosiasi Penyelenggara Jasa Internet Indonesia, Viewed 10 September 2015, www.apjii.or.id

Santos, Gina Gaio. (2015). Narratives about Work and Family Life among Portuguese Academics. Gender, Work and Organization. Vol. 22 Ni1. January 2015 doi:10.1111/gwao.12061.

Badan Pusat Statistik. Statistik Indonesia 2018

Sydie, R. (1987). Natural Women, Cultured Men: A Feminist Perspective on Sociological Theory, Methuen Publications, Ontario.

Undang-Undang Republik Indonesia Nomor 13 Tahun 2003 tentang ketenagakerjaan.

Walby, S. (1990) Theorizing Patriarchy, Blackwell Publishers Ltd, Oxford, UK and Cambridge, USA. 